telescope's main mirror and eliminate the diffraction pattern. The design, which in 2012 won him a 'genius' grant from the MacArthur Foundation, allows the starlight to be thrown away without sacrificing light from the planet. Guyon says that his device could enable a 4-metre telescope, half the diameter of the TPF, to see an Earth twin - but whether it could enable a 2.4-metre telescope to find Earths remains to be seen. "We're still in the grey zone," he says.
Dust adds to the uncertainty. Asteroid collisions have filled the inner Solar System with a haze of dust that reflects sunlight, creating what is known as zodiacal light. The worst nightmare of planet hunters is the possibility that the dust in other solar systems could generate so much 'exozodiacal' light that Earth-sized orbs would be lost within it. "This is the main non-technological risk for an exo-Earth imaging mission," says Ruslan Belikov, an astrophysicist at the
NASA Ames Research Center in Moffett Field, California. Measuring the levels of exozodiacal light around Sun-like stars is a key goal for a pathfinder mission, he adds.

Even if NASA decides against putting a coronagraph on one of the donated telescopes, says Guyon, he is not about to give up. Finding out if there are other habitable planets in the Galaxy, he says, "is the most interesting question in all of science".

\title{
Japan's stimulus package showers science with cash
}

\author{
But new leadership's largesse brings expectations of fast commercial pay-offs.
}

\section{BY DAVID CYRANOSKI IN TOKYO}

$\mathrm{T}$ Three years ago, the picture for research funding in Japan looked bleak. As part of efforts to slash the national budget by $¥ 3$ trillion (US $\$ 33.5$ billion), the government, led by the Democratic Party of Japan, had proposed sweeping cuts to science, sparking protests from the country's most eminent researchers. Japan's flagship K supercomputer project narrowly escaped being shut down after auditors questioned whether Japan needed to host the world's fastest computer.

Fast-forward to 2013, and Shinzo Abe, head of the newly elected Liberal Democratic Partyled government, seems to have no such doubts. "Of course we must aim for number one," he told reporters after a tour of the supercomputer facility on 11 January.

Science is a big winner in the government's massive $¥ 10.3$-trillion economic stimulus package, approved by the cabinet on 15 January. The stimulus flags up the new leadership's determination that research should pull its weight in dragging Japan's economy out of recession. The supplementary budget provides billions of yen for key fields and significant boosts for many big scientific facilities (see 'Big winners') — including $¥ 8.4$ billion for data links between the K supercomputer and Japan's universities.

Among the many other winners is the SPring-8 synchrotron, which will get $¥ 2.9$ billion to spruce up its ageing beamlines, used for structural studies of materials and proteins. There is also $¥ 16.6$ billion for the international fusion energy project ITER, which has been beset by budgetary difficulties since its inception (see Nature 487, 420; 2012). Meanwhile, the Japanese space agency JAXA will get $¥ 22.9$ billion to refurbish its facilities and to speed up development of ALOS-2, a satellite that will monitor natural disasters and measure atmospheric carbon dioxide levels. The extra cash will keep it on schedule for launch before April next year.

But the biggest beneficiary of the Abe government's stimulus is stem-cell research, especially that geared towards clinical applications. The science ministry alone has earmarked $¥ 21.4$ billion for research on stem cells, mainly focused on induced pluripotent stem (iPS) cells - reprogrammed adult cells, first developed in Japan.

Yoshiki Sasai, who has been wowing biologists and non-scientists alike by growing rudimentary retinas, brain parts and other tissues from stem cells (see Nature 488, 444-446; 2012), has long been negotiating with the government for facilities to link basic research at the Center for Developmental Biology in Kobe, where he works, with clinics and industry. The

\section{BIG WINNERS}

Some of the facilities or fields that receive big funding boosts in Japan's supplementary budget.

\section{IPS CELLS*}

\section{JAXA}

\section{CHIKYU DEEP-SEA DRILLING PROJECT}

SACLA/SPRING-8 $¥$

ITER $\$$

NANOTECH AND MATERIALS

SEA-FLOOR SURVEY

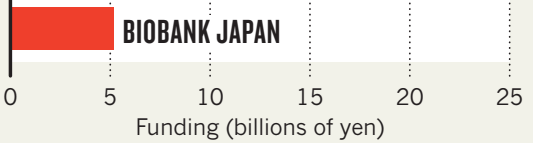
*Induced pluripotent stem cells; †Japanese space agency; ISACLA X-ray
free electron laser/SPring-8 synchrotron; \&lnternational fusion project stimulus package, nonetheless, came "like thunder, out of the blue", he says. The budget includes $¥ 3.8$ billion for a new building at Sasai's centre, with planned projects being largely collaborative ventures with Japanese businesses.

An even bigger windfall will benefit work by Shinya Yamanaka, a Nobel laureate who developed the first recipe for iPS cells. The Center for iPS Cell Research and Application at Kyoto University, which he directs, is to receive $¥ 4$ billion for a building to house research on reprogramming mechanisms and clinical applications of iPS cells. Another $¥ 700$ million will pay to create a cell-processing centre at the Foundation for Biomedical Research and Innovation in Kobe, mainly to support Masayo Takahashi, who works next door at the Center for Developmental Biology. Takahashi is planning the first trial of iPS cells in humans, in a clinical study set to start this year on the eye condition known as macular degeneration.

Other ministries have also jumped on the iPS-cell bandwagon. For example, with $¥ 2.2$ billion the health ministry plans to build two centres to provide training on deriving and cultivating iPS cells.

The stimulus cash could be just the start of the good times for Japan's stem-cell researchers. The government is expected to announce a tenyear, ¥90-billion iPS-cell initiative in next year’s budget, beginning in April.

But the largesse comes with expectations. Of the $¥ 721$ billion earmarked for science and technology by the science ministry, $¥ 180$ billion will go towards translating university research into commercial applications, and most other projects are framed around clinical or industrial applications. With the stimulus, says Yamanaka, the government is "telling us to rush iPS-cell-related technologies to patients as quickly as possible". . 